\title{
Impacts of Fungal Stalk Rot Pathogens on Physicochemical Properties of Sorghum Grain
}

Y. M. A. Y. Bandara, Department of Plant Pathology, Kansas State University, Manhattan 66506; T. T. Tesso, Department of Agronomy, Kansas State University; S. R. Bean and F. E. Dowell, United States Department of Agriculture-Agricultural Research Service, Center for Grain and Animal Health Research, Manhattan KS 66502; and C. R. Little, ${ }^{\dagger}$ Department of Plant Pathology, Kansas State University

\begin{abstract}
Stalk rot diseases are among the most ubiquitous and damaging fungal diseases of sorghum (Sorghum bicolor (L.) Moench) worldwide. Although reports of quantitative yield losses to stalk rots are available, the impact of stalk rot on grain quality attributes is unknown. This study was conducted to test whether stalk rot diseases could affect grain mineral ( $\mathrm{N}, \mathrm{P}, \mathrm{K} ; \mathrm{Ca}, \mathrm{Mg}, \mathrm{Cu}, \mathrm{Fe}, \mathrm{Mn}$, and $\mathrm{Zn}$ ) and macronutrient (protein, fat, and starch) content, ash content, and physical traits (unit grain weight, hardness, and diameter). A field experiment was conducted in 2013 and 2014 with four sorghum genotypes (two hybrids and two lines). Plants from each genotype were inoculated with four stalk rot pathogens (Fusarium andiyazi, $F$. proliferatum, $F$. thapsinum, and Macrophomina phaseolina) and mock-inoculated with phosphate-buffered saline (control). Grains collected from infected and control plants were analyzed for macronutrient and ash content using near-infrared reflectance spectroscopy, grain hardness and diameter using the single-kernel characterization

system, and mineral content using the Rapid Flow Analyzer (Model RFA-300 for N) and inductively coupled plasma spectrometer (for P, $\mathrm{K}, \mathrm{Ca}, \mathrm{Mg}, \mathrm{Cu}, \mathrm{Fe}, \mathrm{Mn}$, and $\mathrm{Zn}$ ). Although stalk rot pathogens significantly reduced unit grain weight, they did not significantly affect grain hardness and diameter and, therefore, may not affect milling quality. Pathogens significantly reduced all macronutrient and most mineral contents across genotypes and environments on a per-unit-grain basis, except $\mathrm{N}$ and $\mathrm{Mg}$, which were affected in a genotype- and environment-specific manner, and Fe, which was not significantly affected. Most minerals tested were significantly and negatively correlated with disease severity (lesion length) and total grain weight per panicle. The hybrid tested (Pioneer 84G62) exhibited reduced mineral and macronutritional changes after stalk rot infection, providing insights into the possibility of producing high-yielding, nutritionally stable hybrids under stalk rot disease pressure through dedicated breeding efforts.
\end{abstract}

Grain sorghum (Sorghum bicolor (L.) Moench), the fifth major cereal crop in the world regarding production (FAO 2007), is grown as feed and grain for industrial uses in the Americas and Australia. Africa and Asia grow it as a food (Dykes et al. 2005, Rooney and Waniska 2000). Nevertheless, with the discovery of the healthassociated benefits of sorghum, including its gluten-free characteristics, low glycemic index, cholesterol-lowering properties, and anti-inflammatory and anticarcinogenic properties, sorghum is becoming more popular as a food in the United States (Bralley et al. 2008; Burdette et al. 2010; Moraes et al. 2012; Turner et al. 2006; Yang et al. 2009). Food products such as bread, cookies, cakes, tortilla chips, and tortillas can be made using sorghum (Dykes and Rooney 2006; Taylor et al. 2006).

Sorghum production can be constrained by many abiotic and biotic factors. Among the biotic factors, stalk rots are pervasive and devastating diseases of sorghum worldwide (Tesso et al. 2010). Stalk rots are characterized by the degradation of pith tissue at or near the base of the stalk, leading to pith cell death (Edmunds 1964). Infection usually results in reduced nutrient and water absorption and translocation due to damaged vascular and cortical tissues in both the roots and stalks (Hundekar and Anahosur 1994). Severe infection can

${ }^{\dagger}$ Corresponding author: C. R. Little; E-mail: crlittle@ksu.edu.

This article is Contribution Number 17-372-J from the Kansas Agricultural Experiment Station, Manhattan.

Names are necessary to report factually on available data; however, the United States Department of Agriculture (USDA) neither guarantees nor warrants the standard of the product, and use of the name by the USDA implies no approval of the product to the exclusion of others that may also be suitable. The USDA is an equal opportunity provider and employer.

Accepted for publication 13 July 2017.

This article is in the public domain and not copyrightable. It may be freely reprinted with customary crediting of the source. The American Phytopathological Society, 2017. result in the disintegration of the structural portions of the root and stalk, leading to plant lodging (Zummo 1984). Impacts of stalk rot diseases on yield components of grain sorghum (Bandara et al. 2017b) and biofuel traits of sweet sorghum (Bandara et al. 2017a) have been reported. Moreover, stalk rot fungi can reduce leaf chlorophyll content in a genotype- and growth-stage-specific manner (Bandara et al. 2016), which can have an adverse effect on plant photosynthetic capacity. Two prevalent stalk diseases of sorghum are Fusarium stalk rot, caused by Fusarium spp., and charcoal rot, caused by Macrophomina phaseolina (Tassi) Goid. (Tarr 1962). If drought and heat stress are followed by a wet and cool environment at physiological maturity, Fusarium stalk rot may be quite severe (Zummo 1980). Prolonged exposure to high temperatures and drought stress during grain development increases charcoal rot incidence (Edmunds 1964; Tesso et al. 2012).

Sorghum grain quality requirements vary depending on the industrial use and type of final product but are fundamentally determined by grain biochemical and physical characteristics. Although stalkrot-associated quantitative yield losses of sorghum are documented and attributed to impeded grain filling, premature ripening, and plant lodging (Bandara et al. 2017b; Zummo 1984), potentially adverse effects on grain quality characteristics are unknown. If such effects exist, knowledge of these would be essential to develop new sorghum genotypes, which are resilient to stalk-rot-mediated quality impacts, and to formulate remedies such as nutrient fortification when sorghum is used in the food and feed industries.

Stalk rot diseases are reported to impede sorghum grain filling (Bandara et al. 2017b; Zummo 1984). Bandara et al. (2017b) showed that stalk rot pathogen inoculations at 14 days after anthesis did not significantly affect grain number. Therefore, the most appropriate basis on which to assess the impact of stalk rots on grain chemical properties such as mineral and macronutrient content is per unit grain. However, it is also possible that certain sorghum genotypes compensate for per-unit-grain mineral and macronutrient reductions through the production of high grain numbers. This way, the plant still maintains a high mineral and macronutrient content when considered on a per-panicle basis. Therefore, measuring pathogen effects on a total grain weight per panicle basis is also important from a sorghum 
production standpoint. We hypothesize that stalk rot pathogens can affect sorghum grain chemical properties on the basis of both per unit grain and total grain weight per panicle. We also hypothesize that stalk rot pathogens can affect seed physical traits. Therefore, the objectives of this study were to investigate the potential adverse effects of stalk rot pathogens on (i) the content of the three primary macronutrients (protein, fat, and starch) and ash content, (ii) mineral content (N, P, K, Ca, $\mathrm{Mg}, \mathrm{Cu}, \mathrm{Fe}, \mathrm{Mn}$, and $\mathrm{Zn}$ ) on a per unit grain and total grain weight per panicle bases, and (iii) physical properties of sorghum grain, including grain weight, hardness, and diameter.

\section{Materials and Methods}

Sorghum genotypes and fungal pathogens. Four sorghum genotypes (two inbred lines and two hybrids) were used for this study.
BTx3042 (Fusarium stalk rot and charcoal rot susceptible) and SC599R (Fusarium stalk rot and charcoal stalk rot resistant) were the two breeding lines used. The two hybrids used were DKS37-07 (Dekalb, charcoal rot resistant) and 84G62 (Dupont Pioneer, charcoal rot tolerant). These are popular hybrids among farmers in the state of Kansas. The stalk rot pathogens that were used in this study included Fusarium andiyazi Marasas, Rheeder, Lampr. K. A. Zeller \& J. F. Leslie; F. proliferatum (Matsush.) Nirenberg ex Gerlach \& Nirenberg; F. thapsinum Klittich, J. F. Leslie, P. E. Nelson \& Marasas; and M. phaseolina. The three Fusarium spp. were obtained from the culture collection of the Row Crops Pathology Lab in the Department of Plant Pathology at Kansas State University. Information on the cultural and molecular identification of Fusarium isolates used can be found in Bandara et al. (2015). The charcoal rot pathogen M. phaseolina

Table 1. $P$ values of $F$ tests from analysis of variance for grain mineral, macronutrient, and ash content (per unit grain weight basis) in four sorghum genotypes after stalk inoculation with Fusarium thapsinum, F. andiyazi, F. proliferatum, Macrophomina phaseolina, or phosphate-buffered saline (mock-inoculated control) in two environments (2013, Manhattan, KS and 2014, Ashland, KS; $\alpha=0.05)^{\mathrm{z}}$

\begin{tabular}{|c|c|c|c|c|c|c|c|c|c|c|c|c|c|}
\hline \multirow[b]{2}{*}{ Effect } & \multicolumn{9}{|c|}{ Minerals } & \multicolumn{3}{|c|}{ Macronutrients } & \multirow[b]{2}{*}{ Ash } \\
\hline & $\mathbf{N}$ & $\mathbf{P}$ & $\mathbf{K}$ & $\mathbf{C a}$ & Mg & $\mathbf{C u}$ & $\mathbf{F e}$ & Mn & Zn & Protein & Fat & Starch & \\
\hline Environment (E) & 0.5395 & 0.0014 & $<0.0001$ & $<0.0001$ & $<0.0001$ & 0.0012 & $<0.0001$ & 0.0614 & $<0.0001$ & 0.0228 & $<0.0001$ & $<0.0001$ & $<0.0001$ \\
\hline Genotype (G) & $<0.0001$ & 0.0001 & 0.0007 & 0.0532 & 0.0006 & $<0.0001$ & $<0.0001$ & $<0.0001$ & 0.0125 & $<0.0001$ & $<0.0001$ & $<0.0001$ & $<0.0001$ \\
\hline $\mathrm{E} \times \mathrm{G}$ & $<0.0001$ & $<0.0001$ & $<0.0001$ & 0.0003 & $<0.0001$ & 0.0028 & 0.0005 & 0.3708 & 0.0002 & 0.0003 & 0.0049 & $<0.0001$ & 0.0111 \\
\hline Pathogen (P) & 0.0059 & $<0.0001$ & $<0.0001$ & 0.0337 & 0.0018 & 0.0116 & 0.0849 & 0.0005 & 0.0082 & 0.0018 & $<0.0001$ & 0.0050 & $<0.0001$ \\
\hline $\mathrm{E} \times \mathrm{P}$ & 0.7679 & 0.7367 & 0.4091 & 0.6165 & 0.8528 & 0.2725 & 0.4398 & 0.1004 & 0.2878 & 0.8000 & 0.7993 & 0.6236 & 0.7287 \\
\hline $\mathrm{G} \times \mathrm{P}$ & 0.0534 & 0.4128 & 0.3479 & 0.9506 & 0.7412 & 0.1009 & 0.5423 & 0.3714 & 0.5761 & 0.6982 & 0.9581 & 0.7896 & 0.5408 \\
\hline $\mathrm{E} \times \mathrm{G} \times \mathrm{P}$ & 0.0062 & 0.0808 & 0.2950 & 0.4937 & 0.0255 & 0.3865 & 0.2970 & 0.3377 & 0.5076 & 0.0669 & 0.4254 & 0.4131 & 0.0628 \\
\hline
\end{tabular}

${ }^{\mathrm{z}} \mathrm{N}, \mathrm{P}, \mathrm{K}, \mathrm{Ca}$, and $\mathrm{Mg}$ in micrograms; $\mathrm{Cu}, \mathrm{Fe}, \mathrm{Mn}$, and $\mathrm{Zn}$ in nanograms; and macronutrients (protein, fat, and starch) and ash in milligrams.
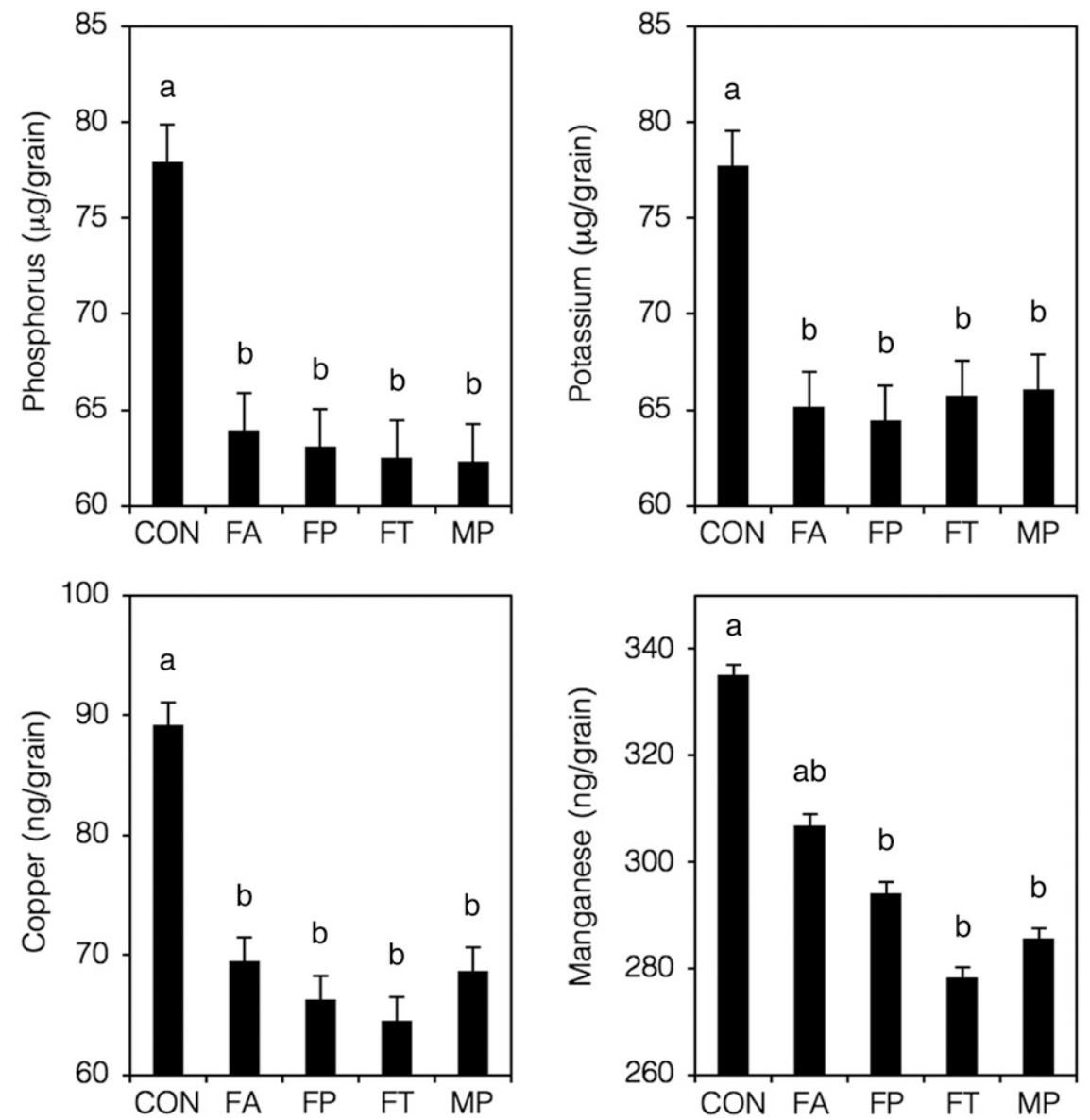
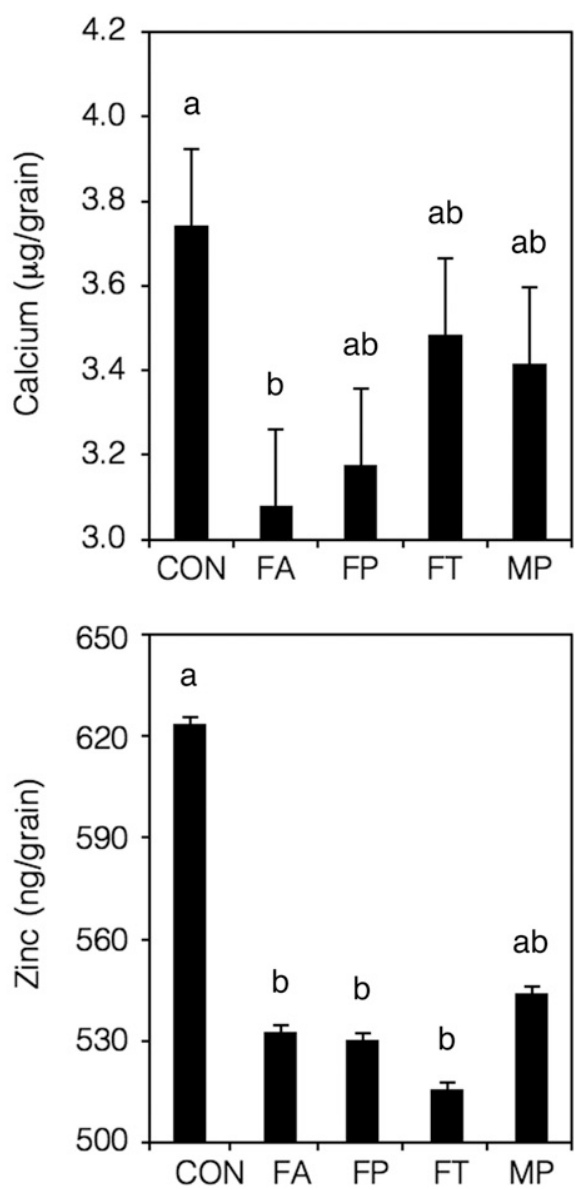

Fig. 1. Comparison of effects of stalk inoculations with four fungal pathogens on mean grain $\mathrm{P}, \mathrm{K}, \mathrm{Ca}, \mathrm{Cu}, \mathrm{Mn}$, and $\mathrm{Zn}$ content ( \pm standard error) across four sorghum genotypes and two environments (2013, Manhattan, KS and 2014, Ashland, KS) using Tukey-Kramer's test. Means followed by the same letters are not significantly different based upon the adjusted $P$ value for multiple comparisons at $\alpha=0.05$. CON $=$ phosphate-buffered saline control, $\mathrm{FA}=$ Fusarium andiyazi, FP $=F$. proliferatum, FT $=F$. thapsinum, and $\mathrm{MP}=$ Macrophomina phaseolina . 
was provided by Dr. Gary Odvody at Texas A\&M AgriLife Research and Extension, Corpus Christi.

Establishment and maintenance of plants, inoculum preparation, inoculation, and measuring disease severity. Field trials were conducted during the 2013 and 2014 growing seasons at the Kansas State University agronomy research farm near Manhattan, KS $\left(39.22^{\circ} \mathrm{N}, 96.60^{\circ} \mathrm{W}\right)$ and Ashland, $\mathrm{KS}\left(39.13^{\circ} \mathrm{N}, 96.62^{\circ} \mathrm{W}\right)$, respectively (referred to hereafter as "the two environments"). Standard procedures for sorghum were used for field preparation, planting, and crop maintenance. Ethyl mercaptan (captan)-treated seeds $\left(2 \mathrm{ml} \mathrm{kg}^{-1}\right.$ of seed) were planted in rows of $5 \mathrm{~m}$ in length by $0.75 \mathrm{~m}$ in width (80 seeds/plot, 60 to 65 plants/stand, not thinned). A four-by-five factorial treatment structure was deployed, where factors one and two consisted of sorghum genotype and pathogen (or mock-inoculated control) treatment, respectively. The design structure of the experiment was a splitplot with randomized complete blocks in both environments. Genotypes (whole-plot unit) and pathogens/control treatments (subplot unit) were randomly assigned to respective plot units. In both years, the experiment was replicated three times (i.e., three blocks). Three plants in each of the five subplots were tagged at 4 weeks after planting with five
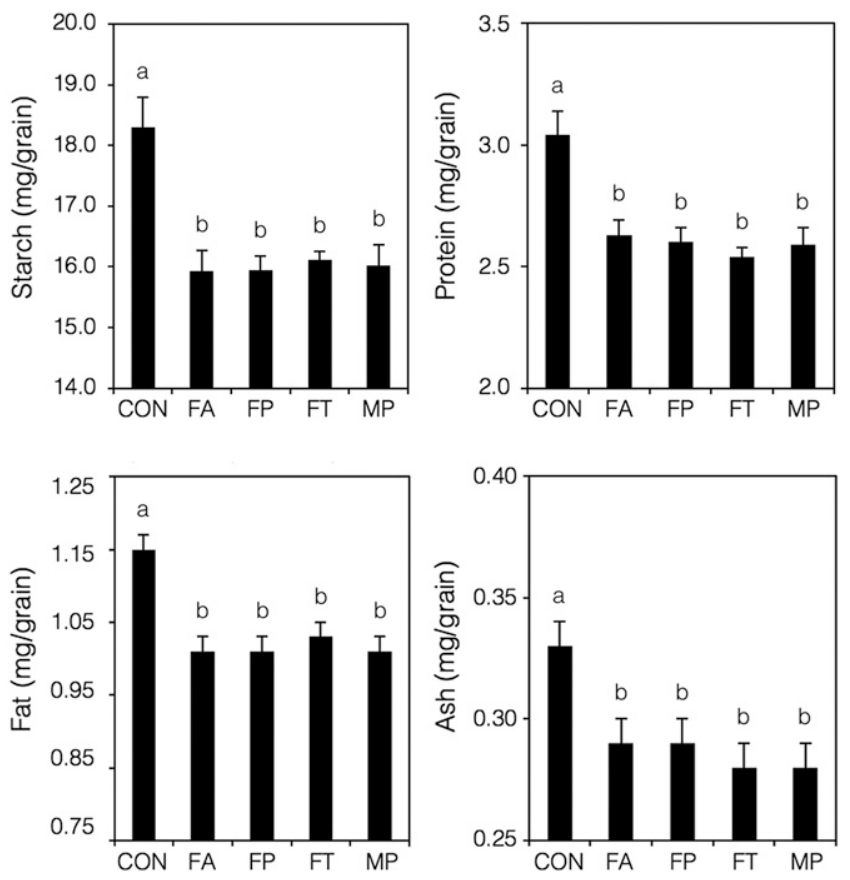

Fig. 2. Comparison of effects of stalk inoculations with four fungal pathogens on mean grain starch, protein, fat, and ash content ( \pm standard error) across four sorghum genotypes and two environments (2013, Manhattan, KS and 2014, Ashland, KS) using Tukey-Kramer's test. Means followed by the same letters are not significantly different based upon the adjusted $P$ value for multiple comparisons at $\alpha=0.05$. $\mathrm{CON}=$ phosphate-buffered saline control, $\mathrm{FA}=$ Fusarium andiyazi, $\mathrm{FP}=F$. proliferatum, $\mathrm{FT}=\mathrm{F}$. thapsinum, and MP = Macrophomina phaseolina. different-colored tapes (three plants of each color) to indicate the pathogen or control treatment they would receive. Therefore, there were three subsample plants (observational units) for each split plot, totaling 180 observational units/environment. Inoculum preparation, inoculation, disease severity measurements, and grain weight measurements were conducted according to the procedures described by Bandara et al. (2017b).

Measurement of minerals, macronutrients, and physical properties of grain. Grains used for mineral determination were drawn from composite samples that consisted of three subsampled panicles per genotype-pathogen treatment combination. The true replicate samples for each genotype-pathogen treatment combination came from three blocks. Therefore, in total, 120 composite samples were evaluated across two environments. Each subsample was tested for macronutrient and physical properties, and mean values were used for statistical analyses.

Grain mineral analysis was performed at the Soil Testing Lab in the Department of Agronomy at Kansas State University. N, P, K, $\mathrm{Ca}, \mathrm{Mg}, \mathrm{Cu}, \mathrm{Fe}, \mathrm{Mn}$, and $\mathrm{Zn}$ content of the grain samples was analyzed. Grain (20 g from each composite sample) was thoroughly ground, and $0.25 \mathrm{~g}$ of the homogenized flour sample was used for the analyses. $\mathrm{N}$ was analyzed by using sulfuric peroxide digest according to the protocols described by Lindner and Harley (1942) and Thomas et al. (1967). The ammonia present in the digest was analyzed by an indophenol blue colorimetric procedure using the Rapid Flow Analyzer (Model RFA-300, RFA Methodology Number A303S072; Alpkem Corporation, Clackamas, OR). Perchloric digests were used to estimate other elements (Gieseking et al. 1935). Digests were analyzed using an inductively coupled plasma (ICP) spectrometer (model 720-ES ICP Optical Emission Spectrometer; Varian Australia Pty Ltd., Mulgrave, VIC, Australia). Near-infrared spectroscopy (NIRS) technology was used to analyze total protein, starch, fat, and ash content in grain. For NIR analysis, each whole-grain sample (20 g) was scanned twice with a DA 7200 NIR spectrometer (Perten Instruments Inc., Springfield, IL), and mean values were recorded (De Alencar Figueiredo et al. 2006). The single-kernel characterization system (SKCS) was used to measure grain hardness and diameter. One hundred grains from each subsample were used for the analysis. SKCS 4100 equipment (Perten Instruments) was controlled by Microsoft Windows software SK4100, v. 2,1,0,1 and was used for analysis according to the methods described by Bean et al. (2006).

The output of the original mineral analysis was percent (grams per 100 grams) for $\mathrm{N}, \mathrm{P}, \mathrm{K}, \mathrm{Ca}$, and $\mathrm{Mg}$ and parts per million for $\mathrm{Cu}, \mathrm{Fe}$, $\mathrm{Mn}$, and $\mathrm{Zn}$. Output for macronutrient NIRS analysis was as a percent. Percent and parts per million values were multiplied by total grain weight per panicle to determine the total weight of mineral or macronutrient content per panicle (minerals in micrograms and macronutrients in grams). This value was divided by the total number of grains per panicle to compute the weight of mineral or macronutrient per unit grain $(\mathrm{N}, \mathrm{P}, \mathrm{K}, \mathrm{Ca}$, and $\mathrm{Mg}$ in micrograms; $\mathrm{Cu}, \mathrm{Fe}, \mathrm{Mn}$, and $\mathrm{Zn}$ in nanograms; and macronutrients in milligrams).

Statistical analysis. SAS software (version 9.2; SAS Institute 2008) was used for data analysis. The PROC GLIMMIX procedure with the restricted maximum-likelihood method was used to estimate

Table 2. $P$ values of $F$ tests from analysis of variance for grain mineral, macronutrient, and ash content (per total grain weight per panicle basis) in four sorghum genotypes after stalk inoculation with Fusarium thapsinum, F. andiyazi, F. proliferatum, Macrophomina phaseolina, or phosphate-buffered saline (mockinoculated control) in two environments (2013, Manhattan, KS and 2014, Ashland, KS) $(\alpha=0.05)^{\mathrm{Z}}$

\begin{tabular}{|c|c|c|c|c|c|c|c|c|c|c|c|c|c|}
\hline \multirow[b]{2}{*}{ Effect } & \multicolumn{9}{|c|}{ Minerals } & \multicolumn{3}{|c|}{ Macronutrients } & \multirow[b]{2}{*}{ Ash } \\
\hline & $\mathbf{N}$ & $\mathbf{P}$ & $\mathbf{K}$ & $\mathbf{C a}$ & Mg & $\mathrm{Cu}$ & $\mathrm{Fe}$ & Mn & Zn & Protein & Fat & Starch & \\
\hline Environment (E) & $<0.0001$ & $<0.0001$ & $<0.0001$ & $<0.0001$ & $<0.0001$ & $<0.0001$ & $<0.0001$ & $<0.0001$ & $<0.0001$ & $<0.0001$ & $<0.0001$ & $<0.0001$ & $<0.0001$ \\
\hline Genotype (G) & $<0.0001$ & $<0.0001$ & $<0.0001$ & 0.0032 & $<0.0001$ & 0.0004 & $<0.0001$ & $<0.0001$ & $<0.0001$ & $<0.0001$ & $<0.0001$ & $<0.0001$ & $<0.0001$ \\
\hline $\mathrm{E} \times \mathrm{G}$ & 0.0067 & 0.0001 & 0.0002 & 0.0643 & 0.0002 & 0.0141 & 0.0011 & 0.0081 & 0.0002 & 0.0017 & 0.0017 & $<0.0001$ & 0.0013 \\
\hline Pathogen $(\mathrm{P})$ & $<0.0001$ & $<0.0001$ & $<0.0001$ & 0.0003 & $<0.0001$ & $<0.0001$ & 0.0008 & $<0.0001$ & $<0.0001$ & $<0.0001$ & $<0.0001$ & $<0.0001$ & $<0.0001$ \\
\hline$E \times P$ & 0.9152 & 0.4775 & 0.8416 & 0.2423 & 0.6174 & 0.7514 & 0.3534 & 0.1703 & 0.5921 & 0.6423 & 0.6423 & 0.6348 & 0.5951 \\
\hline $\mathrm{G} \times \mathrm{P}$ & $<0.0001$ & 0.0458 & 0.0787 & 0.2726 & 0.0357 & 0.0269 & 0.1727 & 0.0049 & 0.0200 & 0.0072 & 0.0072 & 0.0543 & 0.0080 \\
\hline $\mathrm{E} \times \mathrm{G} \times \mathrm{P}$ & $<0.0001$ & 0.0455 & 0.1275 & 0.3408 & 0.0080 & 0.1271 & 0.0781 & 0.0725 & 0.0991 & 0.0013 & 0.0013 & 0.0523 & 0.0131 \\
\hline
\end{tabular}

${ }^{\mathrm{z}}$ Grain minerals in milligrams and macronutrients and ash in grams. 
variance components for fixed factors and effects while the KenwardRoger option was used to compute the denominator degrees of freedom in $F$ tests. Environment, genotype, and pathogen were considered fixed factors and block was considered a random factor nested within environment. In the case of all response variables (nine minerals, three macromolecules and ash, grain hardness, unit grain weight, and diameter), the models' assumptions were tested using Studentized residual plots (for identical and independent distribution of residuals) and Q-Q plots (for normality of residuals). Appropriate heterogeneous variance models were fitted whenever heteroskedasticity was observed by specifying a random or group statement (group = genotype or inoculation treatment) after the model statement. The most suitable models that best fit the data were selected using Bayesian information criterion. Means separations were carried out using the PROC GLIMMIX procedure of SAS. For factors having main effects for response variables, means were compared with adjustments for multiple comparisons using the Tukey-Kramer test. The Bonferroni adjustment was used to compare factor level means with simple or marginal effects. Here, only relevant pairwise comparisons were considered for determining the critical comparison-wise error rate $\left(\alpha_{\mathrm{CER}}\right)$. These $\alpha_{\mathrm{CER}}$ values were subsequently compared against unadjusted $P$ values resulting from Bonferroni correction to test the significance of treatment mean differences. The PROC CORR procedure of SAS was used to compute the Pearson correlation coefficients and significance levels between minerals and lesion length and total grain weight per panicle.

\section{Results}

Mineral content per unit grain weight basis. When minerals were analyzed on a per-unit-grain basis, significant pathogen main effects were evident for $\mathrm{P}$ and $\mathrm{K}(P<0.0001)$, $\mathrm{Ca}(P=0.0337)$, $\mathrm{Cu}(P=0.0116), \mathrm{Mn}(P=0.0005)$, and $\mathrm{Zn}(P=0.0082)$ (Table 1$)$. The three-way interaction between environment, genotype, and pathogen was significant for $\mathrm{N}(P<0.0062)$ and $\mathrm{Mg}(P=0.0255)$. No significant main or simple pathogen treatment effects were evident for $\mathrm{Fe}$. All pathogens significantly reduced $\mathrm{P}, \mathrm{K}, \mathrm{Cu}$, and $\mathrm{Zn}$ content compared with controls (Fig. 1). In all four cases, no significant differences were observed among pathogens. On average, the four stalk rot pathogens reduced $\mathrm{P}, \mathrm{K}, \mathrm{Cu}$, and $\mathrm{Zn}$ content in grain by $19,16,23$, and $15 \%$, respectively. Furthermore, $F$. andiyazi significantly reduced Ca content compared with the control by $17 \%$ (Fig. 1). In comparison with the control, F. proliferatum, $F$. thapsinum, and M. phaseolina significantly reduced $\mathrm{Mn}$ content, although no significant differences were observed among them (Fig. 1). On average, these three pathogens reduced Mn by $15 \%$ compared with controls. In 2013, F. thapsinum and $M$. phaseolina significantly reduced the $\mathrm{N}$ content in BTx3042 grain compared with $F$. andiyazi $(P<0.005)$. All four pathogens significantly reduced $\mathrm{N}$ content of DKS37-07 grain compared with the control $(P<0.005)$ by $34 \%$. In comparison with the control, $F$. thapsinum, $M$. phaseolina, and $F$. andiyazi significantly reduced the $\mathrm{N}$ content of SC599 grain $(P<0.005)$ by 42,30 , and $31 \%$, respectively. Pathogen inoculations did not significantly affect grain $\mathrm{N}$ content in 2014. In 2013, F. proliferatum significantly reduced Mg in DKS3707 grain by $27 \%$ compared with the control, whereas no significant impact of pathogens on $\mathrm{Mg}$ content was observed in 2014.

Macronutrients and ash content per unit grain weight basis. When macronutrients were analyzed on a per-unit-grain basis, pathogens had significant main effects on protein $(P=0.0018)$, fat $(P<$ $0.0001)$, starch $(P=0.005)$, and ash content $(P<0.0001)$ (Table 1$)$. In comparison with controls, the four pathogens significantly reduced all macronutrients and ash content across genotypes and environments (Fig. 2). No significant differences were observed between pathogens. The pathogens reduced protein, fat, starch, and ash by 15 , 12,13 , and $13 \%$, respectively, compared with controls.

Mineral content per total grain weight per panicle basis. When minerals were analyzed on the basis of milligrams per grain weight per panicle, the three-way interaction between environment, genotype, and pathogen was significant for $\mathrm{N}(P<0.0001), \mathrm{P}(P=0.0455)$, and $\mathrm{Mg}$ $(P=0.008)$ content (Table 2). Pathogen effects on $\mathrm{Cu}(P=0.0269)$, $\operatorname{Mn}(P=0.0049)$, and $\mathrm{Zn}(P=0.0200)$ were found to be only genotype specific, whereas the main effect of pathogens was evident for $\mathrm{K}$ $(P<0.0001), \mathrm{Ca}(P=0.0003)$, and $\mathrm{Fe}(P=0.0008)$.

In 2013 , there were no differences among the control treatment and the four pathogens tested for $\mathrm{N}, \mathrm{P}$, and $\mathrm{Mg}$ in 84G62, although significant differences were evident in 2014 (Table 3). Compared

Table 3. Mean mineral contents (milligrams per total grain weight per panicle) of sorghum genotypes after stalk inoculation with $F$. andiyazi, $F$. proliferatum, F. thapsinum, Macrophomina phaseolina, or phosphate-buffered saline (mock-inoculated control) in 2013 (Manhattan, KS) and 2014 (Ashland, KS)

\begin{tabular}{|c|c|c|c|c|c|c|c|c|c|}
\hline \multirow[b]{2}{*}{ Genotype, pathogen } & \multicolumn{3}{|c|}{2013} & \multicolumn{3}{|c|}{2014} & \multirow[b]{2}{*}{$\mathbf{C u}$} & \multirow[b]{2}{*}{ Mn } & \multirow[b]{2}{*}{$\mathbf{Z n}$} \\
\hline & $\mathbf{N}$ & $\mathbf{P}$ & Mg & $\mathbf{N}$ & $\mathbf{P}$ & Mg & & & \\
\hline \multicolumn{10}{|l|}{$84 \mathrm{G} 62$} \\
\hline Control & $1,110.0$ & 331.0 & 143.3 & $1,104.6 \mathrm{a}$ & $172.1 \mathrm{a}$ & $91.1 \mathrm{a}$ & 0.20 & $1.18 \mathrm{a}$ & 1.96 \\
\hline F. andiyazi & $1,123.3$ & 298.7 & 140.0 & $732.3 \mathrm{~b}$ & $115.7 \mathrm{c}$ & $59.0 \mathrm{c}$ & 0.17 & $1.07 \mathrm{ac}$ & 1.81 \\
\hline F. proliferatum & $1,093.3$ & 285.0 & 133.3 & $564.6 \mathrm{bc}$ & $95.6 \mathrm{bc}$ & $45.7 \mathrm{bc}$ & 0.16 & $0.85 \mathrm{bc}$ & 1.57 \\
\hline F. thapsinum & 880.0 & 256.0 & 116.7 & $444.9 \mathrm{c}$ & $61.8 \mathrm{~b}$ & $33.7 \mathrm{~b}$ & 0.15 & $0.70 \mathrm{~b}$ & 1.36 \\
\hline M. phaseolina & 936.7 & 261.7 & 120.0 & $518.0 \mathrm{bc}$ & $62.0 \mathrm{~b}$ & $36.5 \mathrm{~b}$ & 0.16 & $0.78 \mathrm{bc}$ & 1.41 \\
\hline \multicolumn{10}{|l|}{ BTx3042 } \\
\hline Control & $816.7 \mathrm{a}$ & $201.0 \mathrm{a}$ & 90.0 & $774.7 \mathrm{a}$ & $119.9 \mathrm{a}$ & $57.0 \mathrm{a}$ & $0.19 \mathrm{a}$ & $0.59 \mathrm{a}$ & $1.13 \mathrm{a}$ \\
\hline F. andiyazi & $830.0 \mathrm{a}$ & $165.3 \mathrm{ab}$ & 73.3 & $507.2 \mathrm{~b}$ & $66.8 \mathrm{~b}$ & $33.3 \mathrm{~b}$ & $0.15 \mathrm{ab}$ & $0.44 \mathrm{ab}$ & $0.82 \mathrm{~b}$ \\
\hline F. proliferatum & $650.0 \mathrm{ab}$ & $145.7 \mathrm{ab}$ & 66.7 & $526.2 \mathrm{~b}$ & $69.0 \mathrm{~b}$ & $34.7 \mathrm{~b}$ & $0.12 \mathrm{ab}$ & $0.43 \mathrm{ab}$ & $0.88 \mathrm{~b}$ \\
\hline F. thapsinum & $523.3 \mathrm{ab}$ & $119.7 \mathrm{ab}$ & 56.7 & $490.2 \mathrm{~b}$ & $70.8 \mathrm{~b}$ & $33.8 \mathrm{~b}$ & $0.10 \mathrm{~b}$ & $0.38 \mathrm{~b}$ & $0.71 \mathrm{~b}$ \\
\hline M. phaseolina & $413.3 \mathrm{~b}$ & $100.7 \mathrm{~b}$ & 46.7 & $440.0 \mathrm{~b}$ & $61.5 \mathrm{~b}$ & $30.3 \mathrm{~b}$ & $0.10 \mathrm{~b}$ & $0.33 \mathrm{~b}$ & $0.65 \mathrm{~b}$ \\
\hline \multicolumn{10}{|l|}{ DKS37-07 } \\
\hline Control & $1456.7 \mathrm{a}$ & $320.7 \mathrm{a}$ & $156.7 \mathrm{a}$ & $979.4 \mathrm{a}$ & $172.9 \mathrm{a}$ & $78.6 \mathrm{a}$ & $0.14 \mathrm{a}$ & $1.02 \mathrm{a}$ & $1.78 \mathrm{a}$ \\
\hline F. andiyazi & $766.7 \mathrm{~b}$ & $201.7 \mathrm{~b}$ & $96.7 \mathrm{~b}$ & $565.0 \mathrm{~b}$ & $91.0 \mathrm{~b}$ & $44.9 \mathrm{~b}$ & $0.07 \mathrm{~b}$ & $0.68 \mathrm{~b}$ & $1.17 \mathrm{~b}$ \\
\hline F. proliferatum & $700.0 \mathrm{~b}$ & $178.0 \mathrm{~b}$ & $83.3 \mathrm{~b}$ & $651.9 \mathrm{~b}$ & $103.0 \mathrm{~b}$ & $50.5 \mathrm{~b}$ & $0.07 \mathrm{~b}$ & $0.69 \mathrm{~b}$ & $1.09 \mathrm{~b}$ \\
\hline F. thapsinum & $483.3 \mathrm{~b}$ & $116.3 \mathrm{~b}$ & $56.7 \mathrm{~b}$ & $570.7 \mathrm{~b}$ & $94.7 \mathrm{~b}$ & $45.8 \mathrm{~b}$ & $0.06 \mathrm{~b}$ & $0.49 \mathrm{~b}$ & $0.84 \mathrm{~b}$ \\
\hline M. phaseolina & $513.3 \mathrm{~b}$ & $133.7 \mathrm{~b}$ & $63.3 \mathrm{~b}$ & $576.8 \mathrm{~b}$ & $81.9 \mathrm{~b}$ & $42.8 \mathrm{~b}$ & $0.06 \mathrm{~b}$ & $0.50 \mathrm{~b}$ & $0.85 \mathrm{~b}$ \\
\hline \multicolumn{10}{|l|}{ SC599 } \\
\hline Control & $1143.3 \mathrm{a}$ & $240.7 \mathrm{a}$ & $116.7 \mathrm{a}$ & $750.9 \mathrm{a}$ & $134.7 \mathrm{a}$ & $64.5 \mathrm{a}$ & $0.34 \mathrm{a}$ & $0.80 \mathrm{a}$ & $1.81 \mathrm{a}$ \\
\hline F. andiyazi & $566.7 \mathrm{~b}$ & $151.0 \mathrm{~b}$ & $70.0 \mathrm{~b}$ & $440.3 \mathrm{~b}$ & $77.5 \mathrm{~b}$ & $38.8 \mathrm{~b}$ & $0.16 \mathrm{~b}$ & $0.58 \mathrm{~b}$ & $1.08 \mathrm{~b}$ \\
\hline F. proliferatum & $543.3 \mathrm{~b}$ & $128.3 \mathrm{~b}$ & $63.3 \mathrm{~b}$ & $311.0 \mathrm{~b}$ & $54.2 \mathrm{~b}$ & $27.9 \mathrm{~b}$ & $0.15 \mathrm{~b}$ & $0.44 \mathrm{~b}$ & $0.88 \mathrm{~b}$ \\
\hline F. thapsinum & $853.3 \mathrm{ab}$ & $182.3 \mathrm{ab}$ & $86.7 \mathrm{ab}$ & $347.7 \mathrm{~b}$ & $54.3 \mathrm{~b}$ & $28.4 \mathrm{~b}$ & $0.18 \mathrm{~b}$ & $0.47 \mathrm{~b}$ & $1.06 \mathrm{~b}$ \\
\hline M. phaseolina & $790.0 \mathrm{ab}$ & $169.0 \mathrm{ab}$ & $83.3 \mathrm{ab}$ & $352.3 \mathrm{~b}$ & $55.8 \mathrm{~b}$ & $28.7 \mathrm{~b}$ & $0.18 \mathrm{~b}$ & $0.47 \mathrm{~b}$ & $1.07 \mathrm{~b}$ \\
\hline
\end{tabular}

${ }^{\mathrm{z}}$ Means within columns followed by the same letter and means without letter designations are not significantly different based upon the adjustment for multiple comparisons using Bonferroni correction $\left(\alpha_{\mathrm{CER}}=0.005\right) . \mathrm{Cu}, \mathrm{Mn}$, and $\mathrm{Zn}$ values represent means across two environments. 
with controls, $F$. andiyazi, $F$. proliferatum, $F$. thapsinum, and $M$. phaseolina significantly reduced $\mathrm{N}$ by $34,49,60$, and $53 \%$; $\mathrm{P}$ by $33,45,64$, and $64 \%$; and $\mathrm{Mg}$ by $35,50,63$, and $60 \%$, respectively. $\mathrm{Cu}$ and $\mathrm{Zn}$ content were not significantly reduced by pathogens in either environment, whereas $F$. proliferatum, $F$. thapsinum, and M. phaseolina significantly reduced Mn content by 30, 40, and 34\%, respectively, compared with controls.

In 2013, M. phaseolina was the only pathogen that significantly reduced the $\mathrm{N}$ and $\mathrm{P}$ content of $\mathrm{BT} \times 3042$ grain in comparison with the control (49 and 50\%, respectively). Pathogens did not significantly reduce $\mathrm{Mg}$ content. However, all pathogens, on average, significantly reduced $\mathrm{N}(37 \%), \mathrm{P}(44 \%)$, and $\mathrm{Mg}(42 \%)$ content compared with the control treatment in 2014 , although no significant differences among pathogens were observed. All pathogens, on average, significantly reduced $\mathrm{Zn}$ content by $32 \%$ across both environments compared with the control, while $F$. thapsinum and M. phaseolina, on average, reduced $\mathrm{Cu}$ and $\mathrm{Mn}$ content in comparison with controls by 47 and $40 \%$, respectively.

On average, the four pathogens significantly reduced DKS37-07 N, P, and $\mathrm{Mg}$ under both environments (58, 51, and 52\% in 2013 and 40, 46, and $42 \%$ in 2014). The same phenomenon was observed for $\mathrm{Cu}, \mathrm{Mn}$, and $\mathrm{Zn}$, which were reduced by 54,42 , and $45 \%$ across environments.

The N, P, and Mg content of SC599 were not significantly reduced by F. thapsinum or M. phaseolina compared with the control in 2013 but $F$. andiyazi and $F$. proliferatum reduced $\mathrm{N}, \mathrm{P}$, and $\mathrm{Mg}$ by 52,42 , and $43 \%$, respectively (Table 3 ). However, all pathogens, on average, significantly reduced the $\mathrm{N}, \mathrm{P}$, and $\mathrm{Mg}$ by 52,55 , and $52 \%$, respectively, in 2014. $\mathrm{Cu}, \mathrm{Mn}$, and $\mathrm{Zn}$ were reduced by 51, 39, and $44 \%$, respectively, across environments compared with controls.

Pathogens had significant main effects on $\mathrm{K}, \mathrm{Ca}$, and $\mathrm{Fe}$ content. $F$. andiyazi, $F$. proliferatum, $F$. thapsinum, and $M$. phaseolina significantly reduced $\mathrm{K}(148.7,136.6,127.1$, and $123.6 \mathrm{mg}$, respectively), $\mathrm{Ca}(7.3,6.8,6.6$, and $6.7 \mathrm{mg}$, respectively), and $\mathrm{Fe}(1.8,1.9,1.5$, and

Table 4. Mean protein, fat, and ash contents (grams per total grain weight per panicle) as determined by near-infrared reflectance spectroscopy for sorghum genotypes after stalk inoculation with Fusarium andiyazi, F. proliferatum, F. thapsinum, Macrophomina phaseolina, or phosphate-buffered saline (mockinoculated control) in the 2013 (Manhattan, KS) and 2014 (Ashland, KS) experiments $^{\mathrm{z}}$

\begin{tabular}{|c|c|c|c|c|c|c|}
\hline \multirow[b]{2}{*}{ Genotype, pathogen } & \multicolumn{3}{|c|}{2013} & \multicolumn{3}{|c|}{2014} \\
\hline & Protein & Fat & Ash & Protein & Fat & Ash \\
\hline \multicolumn{7}{|l|}{$84 \mathrm{G} 62$} \\
\hline Control & 10.6 & 5.1 & $1.33 \mathrm{a}$ & $9.1 \mathrm{a}$ & $3.7 \mathrm{a}$ & $1.04 \mathrm{a}$ \\
\hline F. andiyazi & 10.5 & 4.7 & $1.23 \mathrm{ab}$ & $5.8 \mathrm{~b}$ & $2.4 \mathrm{c}$ & $0.70 \mathrm{c}$ \\
\hline F. proliferatum & 9.9 & 4.5 & $1.18 \mathrm{ab}$ & $4.6 \mathrm{bc}$ & $1.9 \mathrm{bc}$ & $0.55 \mathrm{bc}$ \\
\hline F. thapsinum & 8.5 & 4.0 & $1.03 \mathrm{~b}$ & $3.7 \mathrm{c}$ & $1.6 \mathrm{~b}$ & $0.43 \mathrm{~b}$ \\
\hline M. phaseolina & 8.8 & 4.0 & $1.07 \mathrm{~b}$ & $4.0 \mathrm{c}$ & $1.7 \mathrm{~b}$ & $0.46 \mathrm{bc}$ \\
\hline \multicolumn{7}{|l|}{ ВТх3042 } \\
\hline Control & $7.1 \mathrm{a}$ & 2.7 & $0.71 \mathrm{a}$ & $5.8 \mathrm{a}$ & $1.6 \mathrm{a}$ & 0.51 \\
\hline F. andiyazi & $6.7 \mathrm{ab}$ & 2.1 & $0.66 \mathrm{a}$ & $3.8 \mathrm{~b}$ & $1.1 \mathrm{~b}$ & 0.33 \\
\hline F. proliferatum & $5.5 \mathrm{ab}$ & 1.9 & $0.56 \mathrm{ab}$ & $4.0 \mathrm{~b}$ & $1.1 \mathrm{~b}$ & 0.36 \\
\hline F. thapsinum & $4.6 \mathrm{ab}$ & 1.7 & $0.47 \mathrm{ab}$ & $3.6 \mathrm{~b}$ & $1.1 \mathrm{~b}$ & 0.32 \\
\hline M. phaseolina & $3.8 \mathrm{~b}$ & 1.4 & $0.40 \mathrm{~b}$ & $3.2 \mathrm{~b}$ & $0.9 \mathrm{~b}$ & 0.27 \\
\hline \multicolumn{7}{|l|}{ DKS37-07 } \\
\hline Control & $11.2 \mathrm{a}$ & $4.4 \mathrm{a}$ & $1.32 \mathrm{a}$ & $7.5 \mathrm{a}$ & $3.1 \mathrm{a}$ & $0.90 \mathrm{a}$ \\
\hline F. andiyazi & $6.9 \mathrm{~b}$ & $3.1 \mathrm{~b}$ & $0.85 \mathrm{~b}$ & $4.4 \mathrm{~b}$ & $1.9 \mathrm{~b}$ & $0.55 \mathrm{~b}$ \\
\hline F. proliferatum & $6.2 \mathrm{bc}$ & $2.9 \mathrm{bc}$ & $0.81 \mathrm{bc}$ & $4.9 \mathrm{~b}$ & $2.1 \mathrm{~b}$ & $0.60 \mathrm{~b}$ \\
\hline F. thapsinum & $3.7 \mathrm{c}$ & $1.8 \mathrm{c}$ & $0.49 \mathrm{~d}$ & $4.5 \mathrm{~b}$ & $2.0 \mathrm{~b}$ & $0.59 \mathrm{~b}$ \\
\hline M. phaseolina & $4.3 \mathrm{bc}$ & $2.0 \mathrm{bc}$ & $0.55 \mathrm{~cd}$ & $4.4 \mathrm{~b}$ & $1.9 \mathrm{~b}$ & $0.55 \mathrm{~b}$ \\
\hline \multicolumn{7}{|l|}{ SC599 } \\
\hline Control & $8.1 \mathrm{a}$ & $2.9 \mathrm{a}$ & $0.85 \mathrm{a}$ & $5.3 \mathrm{a}$ & $1.8 \mathrm{a}$ & 0.49 \\
\hline F. andiyazi & $4.9 \mathrm{~b}$ & $2.0 \mathrm{ab}$ & $0.59 \mathrm{~b}$ & $3.2 \mathrm{~b}$ & $1.2 \mathrm{~b}$ & 0.33 \\
\hline F. proliferatum & $4.5 \mathrm{~b}$ & $1.7 \mathrm{~b}$ & $0.50 \mathrm{~b}$ & $2.5 \mathrm{~b}$ & $0.9 \mathrm{~b}$ & 0.25 \\
\hline F. thapsinum & $6.4 \mathrm{ab}$ & $2.4 \mathrm{ab}$ & $0.65 \mathrm{ab}$ & $2.5 \mathrm{~b}$ & $0.9 \mathrm{~b}$ & 0.25 \\
\hline M. phaseolina & $5.8 \mathrm{ab}$ & $2.0 \mathrm{ab}$ & $0.60 \mathrm{ab}$ & $2.5 \mathrm{~b}$ & $0.9 \mathrm{~b}$ & 0.26 \\
\hline
\end{tabular}

${ }^{\mathrm{z}}$ Means within columns followed by the same letter and means without letter designations are not significantly different based upon the adjustment for multiple comparisons using the Bonferroni correction $\left(\alpha_{\mathrm{CER}}=0.005\right)$.
$1.4 \mathrm{mg}$, respectively) content in comparison with controls $(\mathrm{K}=213.5$, $\mathrm{Ca}=10.6$, and $\mathrm{Fe}=2.4 \mathrm{mg}$ ). In all cases, no significant differences were observed among the pathogens. The four pathogens reduced $\mathrm{K}, \mathrm{Ca}$, and Fe by 37,35 , and $30 \%$, respectively, in comparison with the control treatment.

Macronutrients and ash content per total grain weight per panicle basis. When analyzed in grams per total grain weight per panicle, the three-way interaction effect between environment, genotype, and pathogen was significant for protein $(P=0.0013)$, fat $(P=0.0013)$, and ash $(P=0.0131)$ content (Table 2$)$. The main effect of pathogens was significant for starch content $(P<0.0001)$.

Although pathogens did not significantly affect protein and fat content in 84G62 in 2013, all pathogens significantly reduced protein and fat content in 2014 (Table 4). Ash content was significantly reduced by all pathogens in 2014 and by F. thapsinum and M. phaseolina in 2013. Pathogens did not significantly reduce the fat content of BTx3042 in 2013 or ash content in 2014. M. phaseolina significantly reduced the protein and ash content compared with the control in 2013, whereas all pathogens significantly reduced protein and fat content in 2014. All pathogens significantly reduced protein, fat, and ash of DKS37-07 under both environments. F. andiyazi and $F$. proliferatum significantly reduced the protein and ash content of SC599 in 2013 compared with the control, whereas $F$. proliferatum significantly reduced fat content compared with the control. Pathogens did not reduce ash content of SC599 in 2014 whereas all pathogens significantly reduced protein and fat content. All pathogens significantly reduced starch content over the control treatment across genotypes and environments. Effects of $F$. thapsinum and $M$. phaseolina inoculations were also significantly lower than with $F$. andiyazi inoculations. On average, $F$. thapsinum and $M$. phaseolina caused a $40 \%$ reduction of starch per panicle. The lowest percentage protein, fat, and ash reductions were observed in hybrid 84G62 whereas the highest percentages of those were observed in hybrid DKS37-07.

Analysis of grain physical characteristics. There was no significant pathogen effect on grain hardness and diameter (Table 5). Compared with the control, $F$. andiyazi $(P=0.0003), F$. proliferatum $(P=0.0004)$, $F$. thapsinum $(P=0.0002)$, and $M$. phaseolina $(P=0.0012)$ significantly reduced unit grain weight across genotypes and environments (Fig. 3). No significant differences were observed between pathogens. The pathogens, on average, reduced unit grain weight by $16 \%$ compared with controls.

Correlation analysis between grain mineral content and total grain weight per panicle and lesion length. Some minerals $(\mathrm{N}, \mathrm{P}$, $\mathrm{Mg}$, and $\mathrm{Cu}$ ) were significantly and negatively correlated with total grain weight per panicle and lesion length in both environments under disease pressure. Significant and negative correlations were observed in an environment-dependent manner for other minerals such as Fe and $\mathrm{Zn}$ (Table 6).

\section{Discussion}

When analyzed on a weight per-unit-grain basis, pathogens significantly reduced most of the minerals tested, including $\mathrm{P}, \mathrm{K}, \mathrm{Ca}, \mathrm{Cu}$,

Table 5. $F$ test $P$ values from analysis of variance for seed physical properties measured via single-kernel characterization system with four sorghum genotypes after stalk inoculation with $F$ usarium thapsinum, $F$. andiyazi, $F$. proliferatum, Macrophomina phaseolina, or phosphate-buffered saline (mock-inoculated control) at two environments (2013, Manhattan, KS and 2014, Ashland, KS; $\alpha=0.05)^{\mathrm{z}}$

\begin{tabular}{lccr}
\hline Effect & Hardness & Diameter & Weight \\
\hline Environment $(\mathrm{E})$ & $<0.0001$ & 0.0007 & $<0.0001$ \\
Genotype $(\mathrm{G})$ & $<0.0001$ & 0.0005 & $<0.0001$ \\
$\mathrm{E} \times \mathrm{G}$ & $<0.0001$ & 0.0003 & $<0.0001$ \\
Pathogen $(\mathrm{P})$ & 0.7903 & 0.5539 & 0.0002 \\
$\mathrm{E} \times \mathrm{P}$ & 0.6366 & 0.4090 & 0.9034 \\
$\mathrm{G} \times \mathrm{P}$ & 0.4192 & 0.8909 & 0.7540 \\
$\mathrm{E} \times \mathrm{G} \times \mathrm{P}$ & 0.6358 & 0.3267 & 0.1069 \\
\hline
\end{tabular}

${ }^{\mathrm{z}}$ Hardness is unitless. Unit grain weight and diameter were measured in milligrams and millimeters, respectively. 
$\mathrm{Mn}$, and $\mathrm{Zn}$, across genotypes and environments, revealing the adverse effects of stalk rot pathogens on grain sorghum quality attributes. However, when the analyses were performed on the basis of milligrams per total grain weight per panicle, pathogen effects appeared to be genotype and environment specific for most minerals tested. Such effects showed that some sorghum genotypes could compensate for stalk-rot-mediated grain nutrient depletion through increased grain number and, therefore, increased total grain weight per panicle. The high-yielding hybrid 84G62 was more resilient to stalk-rot-mediated grain mineral reduction compared with hybrid

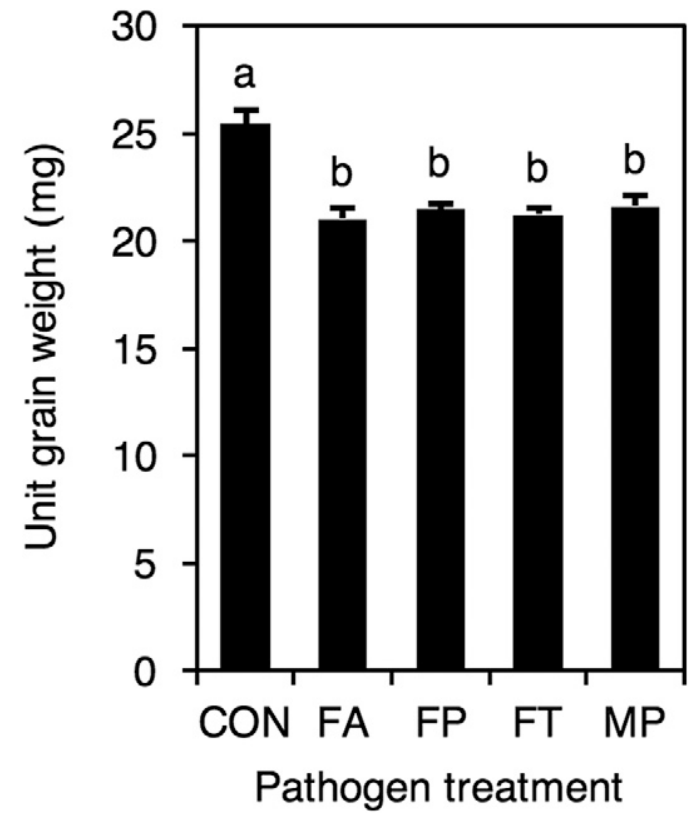

Fig. 3. Comparison of effects of stalk inoculations with four fungal pathogens on mean unit grain weight ( \pm standard error) across four sorghum genotypes and two environments (2013, Manhattan, KS and 2014, Ashland, KS) using Tukey-Kramer's test. Means followed by the same letters are not significantly different based upon the adjusted $P$ value for multiple comparisons at $\alpha=0.05$. $\mathrm{CON}=$ phosphatebuffered saline control, $\mathrm{FA}=$ Fusarium andiyazi, $\mathrm{FP}=F$. proliferatum, $\mathrm{FT}=F$. thapsinum, and MP = Macrophomina phaseolina.
DKS37-07. This indicated that certain hybrids can maintain high yields without compromising grain mineral content under disease pressure while others cannot, which was supported by Pearson correlation analysis (Table 6). Under disease pressure, most mineral nutrients were significantly and negatively correlated with total grain weight per panicle and lesion length in both environments. This indicated that disease severity, as well as total grain weight per panicle, were inversely proportional to mineral content. Although DKS37-07 follows this general trend, the other high-yielding hybrid, 84G62, did not. Thus, room exists for breeders to produce high-yielding hybrids having tolerance to stalk-rot-mediated grain mineral depletion.

When macronutrients were analyzed on the basis of grams per total grain weight per panicle, the hybrid 84G62 was found to be more tolerant to stalk-rot-mediated grain macronutrient reduction than hybrid DKS37-07. However, when analyzed on the basis of milligrams per unit grain weight, stalk rot pathogens reduced all macronutrients regardless of genotype and environment. The effect of stalk rot pathogens on grain starch content was more prominent than the effects on protein and fat. These findings predict impacts on end-use quality of the products manufactured using sorghum grown in pathogeninfested fields. Therefore, regular analysis of mineral and macronutrient content of the sorghum coming from areas vulnerable to stalk rot diseases and follow-up with necessary remedial measures such as mineral and nutrient fortification is important for ensuring end-use quality. Fortification adds an extra cost to the production chain. The costs involved could be quite serious because stalk rots have been reported to be the most prevalent fungal diseases of sorghum throughout the world (Tesso et al. 2010). Sorghum is grown as a basic food staple in many areas of Africa and Asia (Dykes et al. 2005; Rooney and Waniska 2000), where protein malnutrition is a common problem. The potential for food and feed nutrient deficiencies reiterates the importance of breeding new genotypes with improved macronutrient profiles and increased tolerance to stalk-rot-mediated macronutrient depletions.

An objective of this study was to test whether stalk rot pathogens are associated with changes in sorghum grain physical characteristics. Grain hardness is an essential physical kernel attribute that affects grain processing and end-use quality (Bettge and Morris 2000; Cagampang and Kirleis 1984) by affecting milling quality traits such as flour yield and flour ash (Munck 1995; Rooney and Waniska 2000). Moreover, among other contributory factors, grain

Table 6. Pearson correlation coefficients and significance levels among grain mineral composition, total seed weight per panicle (TSW), and lesion length (LL) (disease severity) across four sorghum genotypes after inoculation with phosphate-buffered saline (control) and four fungal pathogens (Fusarium thapsinum, F. andiyazi, F. proliferatum, and Macrophomina phaseolina) in 2013 (Manhattan, KS) and 2014 (Ashland, KS) $(\alpha=0.05)$

\begin{tabular}{|c|c|c|c|c|c|c|c|c|}
\hline \multirow[b]{3}{*}{ Mineral } & \multicolumn{4}{|c|}{2013} & \multicolumn{4}{|c|}{2014} \\
\hline & \multicolumn{2}{|c|}{ Control } & \multicolumn{2}{|c|}{ Four pathogens } & \multicolumn{2}{|c|}{ Control } & \multicolumn{2}{|c|}{ Four pathogens } \\
\hline & TSW & $\mathbf{L L}$ & TSW & $\mathbf{L L}$ & TSW & $\mathbf{L L}$ & TSW & $\mathbf{L L}$ \\
\hline \multirow[t]{2}{*}{$\mathrm{N}$} & $-0.5776^{\mathrm{y}}$ & -0.0911 & -0.5694 & -0.4359 & -0.8487 & 0.3859 & -0.6913 & -0.6724 \\
\hline & $0.0492^{z}$ & 0.7782 & $<0.0001$ & 0.0020 & 0.0005 & 0.2154 & $<0.0001$ & $<0.0001$ \\
\hline \multirow[t]{2}{*}{$\mathrm{P}$} & -0.6095 & -0.0065 & -0.5393 & -0.4764 & -0.7727 & 0.3917 & -0.6453 & -0.5962 \\
\hline & 0.0354 & 0.9841 & $<0.0001$ & 0.0006 & 0.0032 & 0.2080 & $<0.0001$ & $<0.0001$ \\
\hline \multirow[t]{2}{*}{ K } & -0.3789 & -0.1014 & -0.4046 & -0.3255 & -0.4370 & 0.2151 & -0.2377 & -0.3353 \\
\hline & 0.2245 & 0.7539 & 0.0043 & 0.0240 & 0.1555 & 0.5019 & 0.1038 & 0.0198 \\
\hline \multirow[t]{2}{*}{$\mathrm{Ca}$} & -0.5627 & 0.2132 & -0.4274 & -0.1118 & -0.6120 & 0.1970 & 0.5020 & 0.3459 \\
\hline & 0.0568 & 0.5059 & 0.0024 & 0.4492 & 0.0310 & 0.5400 & 0.0035 & 0.0160 \\
\hline \multirow[t]{2}{*}{$\mathrm{Mg}$} & -0.4454 & -0.1759 & -0.5702 & -0.4570 & -0.8171 & 0.4038 & -0.7486 & -0.6849 \\
\hline & 0.1468 & 0.5845 & $<0.0001$ & 0.0011 & 0.0012 & 0.1930 & $<0.0001$ & $<0.0001$ \\
\hline \multirow[t]{2}{*}{$\mathrm{Cu}$} & -0.6482 & -0.0800 & -0.3217 & -0.4799 & -0.6343 & 0.1049 & -0.8348 & -0.6729 \\
\hline & 0.0226 & 0.8049 & 0.0258 & 0.0006 & 0.0267 & 0.7456 & $<0.0001$ & $<0.0001$ \\
\hline \multirow[t]{2}{*}{$\mathrm{Fe}$} & -0.6516 & 0.0544 & 0.2049 & -0.1373 & -0.8311 & 0.4345 & -0.7278 & -0.6742 \\
\hline & 0.0217 & 0.8666 & 0.1625 & 0.3521 & 0.0008 & 0.1581 & $<0.0001$ & $<0.0001$ \\
\hline \multirow[t]{2}{*}{$\mathrm{Mn}$} & -0.2818 & -0.3776 & -0.1866 & -0.4845 & -0.3272 & 0.0428 & -0.1959 & -0.4985 \\
\hline & 0.3748 & 0.2262 & 0.2040 & 0.0005 & 0.2992 & 0.8950 & 0.1820 & 0.0010 \\
\hline \multirow[t]{2}{*}{$\mathrm{Zn}$} & -0.3694 & -0.4483 & -0.2517 & -0.4366 & -0.5810 & 0.1991 & -0.7329 & -0.6556 \\
\hline & 0.2373 & 0.1438 & 0.0844 & 0.0019 & 0.0476 & 0.5351 & $<0.0001$ & $<0.0001$ \\
\hline
\end{tabular}

\footnotetext{
${ }^{y}$ Correlation coefficient.

${ }^{\mathrm{z}}$ Significance level.
} 
hardness plays a role in host defense against fungal pathogens such as F. thapsinum, Curvularia lunata, Alternaria alternata, and Colletotrichum graminicola that cause grain mold in sorghum (Chandrashekar and Mazhar 1999). However, Funnell and Pedersen (2006) used nearisogenic lines that varied at two loci with significantly different grain hardness (as determined by SKCS) but there were no significant differences in grain mold infections. In the current study, despite the observed pathogen-associated grain weight reductions, SKCS analysis did not provide evidence for stalk rot impacts on grain hardness and diameter. The lack of significant differences for grain diameter could have been contributed by the visually observed irregularities of grain shapes coming from the panicles of stalk rot-infected plants.

In general, the adverse effects of stalk rot pathogens on mineral and macronutrient contents were more pronounced in 2014 than 2013. Stalk rot diseases are severe under postflowering drought conditions (Tesso et al. 2005), particularly when the conserved soil moisture content is low (Dodd 1980; Edmunds 1964; Odvody and Dunkle 1979). The total precipitation received during the cultivation period (July to October) in 2014 was $240 \mathrm{~mm}$ whereas that of 2013 was $360 \mathrm{~mm}$. The mean maximum temperature recorded during August (coinciding with the first 2 weeks after anthesis) in 2014 was $33.8^{\circ} \mathrm{C}$ whereas that of 2013 was $31.1^{\circ} \mathrm{C}$. Compared with 2013 , the lower precipitation in combination with the higher temperature could have resulted in less conserved soil moisture in 2014 and contributed to intensified postflowering drought stress conditions. Hence, the conditions in 2014 were likely more conducive to stalk rot manifestation, which led to more pronounced effects on grain mineral and macronutrient content. Overall, this study provided evidence for the negative impacts of stalk rot diseases on sorghum grain physicochemical properties.

\section{Acknowledgments}

We thank the Kansas Grain Sorghum Commission for their financial support of this research and S. Peiris for technical support in performing NIRS analysis.

\section{Literature Cited}

Bandara, Y. M. A. Y., Perumal, R., and Little, C. R. 2015. Integrating resistance and tolerance for improved evaluation of sorghum lines against Fusarium stalk rot and charcoal rot. Phytoparasitica 43:485-499.

Bandara, Y. M. A. Y., Weerasooriya, D. K., Tesso, T. T., and Little, C. R. 2016. Stalk rot fungi affect leaf greenness (SPAD) of grain sorghum in a genotypeand growth stage-specific manner. Plant Dis. 100:2062-2068.

Bandara, Y. M. A. Y., Weerasooriya, D. K., Tesso, T. T., and Little, C. R. 2017a. Stalk rot diseases impact sweet sorghum biofuel traits. BioEnergy Res. 10: 26-35.

Bandara, Y. M. A. Y., Weerasooriya, D. K., Tesso, T. T., Prasad, P. V. V., and Little, C. R. 2017b. Stalk rot fungi affect grain sorghum yield components in an inoculation stage-specific manner. Crop Prot. 94:97-105.

Bean, S. R., Chung, O. K., Tuinstra, M. R., Pedersen, J. F., and Erpelding, J. 2006. Evaluation of the single kernel characterization system (SKCS) for measurement of sorghum grain attributes. Cereal Chem. 83:108-113.

Bettge, A. D., and Morris, C. F. 2000. Relationships among grain hardness, pentosan fractions, and end-use quality of wheat. Cereal Chem. 77:241-247.

Bralley, E., Greenspan, P., Hargrove, J. L., and Hartle, D. K. 2008. Inhibition of hyaluronidase activity by select sorghum brans. J. Med. Food 11:307-312.

Burdette, A., Garner, P. L., Mayer, E. P., Hargrove, J. L., Hartle, D. K., and Greenspan, P. 2010. Anti-inflammatory activity of select sorghum (Sorghum bicolor) brans. J. Med. Food 13:879-887.

Cagampang, G. B., and Kirleis, A. W. 1984. Relationship of sorghum grain hardness to selected physical and chemical measurements of grain quality. Cereal Chem. 61:100-105.

Chandrashekar, A., and Mazhar, H. 1999. The biochemical basis and implications of grain strength in sorghum and maize. J. Cereal Sci. 30:193-207.

de Alencar Figueiredo, L. F., Davrieux, F., Fliedel, G., Rami, J. F., Chantereau, J., Deu, M., Courtois, B., and Mestres, C. 2006. Development of NIRS equations for food grain quality traits through exploitation of a core collection of cultivated sorghum. J. Agric. Food Chem. 54:8501-8509.

Dodd, J. L. 1980. The photosynthetic stress translocation balance concept of sorghum stalk rot. Pages 300-305 in: Proc. Int. Workshop Sorghum Dis. Texas A\&M University/ICRISAT Press, Hyderabad, India.

Dykes, L., and Rooney, L. W. 2006. Sorghum and millet phenols and antioxidants. J. Cereal Sci. 44:236-251.

Dykes, L., Rooney, L. W., Waniska, R. D., and Rooney, W. L. 2005. Phenolic compounds and antioxidant activity of sorghum grains of varying genotypes. J. Agric. Food Chem. 53:6813-6818.

Edmunds, L. K. 1964. Combined relation of plant maturity, temperature and soil moisture to charcoal stalk rot development in grain sorghum. Phytopathology 54:514-517.

FAO. 2007. FAOSTAT ProdStat Database, Yearly Production. Online publication. http://www.fao.org/faostat/en/\#home

Funnell, D. L., and Pedersen, J. F. 2006. Association of plant color and pericarp color with colonization of grain by members of Fusarium and Alternaria in near-isogenic sorghum lines. Plant Dis. 90:411-418.

Gieseking, J. E., Snider, H. J., and Getz, C. A. 1935. Destruction of organic matter in plant material by the use of nitric and perchloric acids. Ind. Eng. Chem. Anal. Ed. 7:185-186.

Hundekar, A. R., and Anahosur, K. H. 1994. Pathogenicity of fungi associated with sorghum stalk rot. Karnataka J. Agric. Sci. 7:291-295.

Lindner, R. C., and Harley, C. P. 1942. A rapid method for the determination of nitrogen in plant tissue. Science 96:565-566.

Moraes, E. A., Natal, D. I. G., Queiroz, V. A. V., Schaffer, R. E., Cecon, P. R., de Paula, S. O., Benjamin, L. D. A., Ribeiro, S. M. R., and Martino, H. S. D. 2012. Sorghum genotypes may reduce low-grade inflammatory response and oxidative stress and maintains jejunum morphology of rats fed a hyperlipidimic diet. Food Res. Int. 49:553-559.

Munck, L. 1995. New milling technologies and products: Whole plant utilization by milling and separation of the botanical and chemical components. Pages 223-281 in: Sorghum and Millets: Chemistry and Technology. D. A. V. Dendy, ed. AACC International, St. Paul, MN.

Odvody, G. N., and Dunkle, L. D. 1979. Charcoal stalk rot of sorghum: Effect of environment on host parasite relations. Phytopathology 69:250-254.

Rooney, L. W., and Waniska, R. D. 2000. Sorghum food and industrial utilization. Pages 689-750 in: Sorghum: Origin, History, Technology, and Production. C. W. Smith and R. A. Frederiksen, eds. John Wiley and Sons, New York.

SAS Institute. 2008. The SAS Users Guide, Version 9.2. Cary, NC.

Tarr, S. A. J. 1962. Root and stalk diseases: Red stalk rot, Colletotrichum rot, anthracnose, and red leaf spot. Pages 58-73 in: Diseases of Sorghum, Sudan Grass and Brown Corn. Commonwealth Mycological Institute, Kew, Surrey, UK.

Taylor, J. R. N., Schober, T. J., and Bean, S. R. 2006. Novel food and nonfood uses for sorghum and millets. J. Cereal Sci. 44:252-271.

Tesso, T., Perumal, R., Little, C. R., Adeyanju, A., Radwan, G. L., Prom, L. K., and Magill, C. W. 2012. Sorghum pathology and biotechnology-A fungal disease perspective: Part II. Anthracnose, stalk rot, and downy mildew. Eur. J. Plant Sci. Biotechnol. 6:31-44.

Tesso, T. T., Claflin, L. E., and Tuinstra, M. R. 2005. Analysis of stalk rot resistance and genetic diversity among drought tolerant sorghum genotypes. Crop Sci. 45:645-652.

Tesso, T. T., Ochanda, N., Little, C. R., Claflin, L., and Tuinstra, M. R. 2010 Analysis of host plant resistance to multiple Fusarium species associated with stalk rot disease in sorghum [Sorghum bicolor (L.) Moench]. Field Crops Res. 118:177-182.

Thomas, R. L., Sheard, R. W., and Moyer, J. R. 1967. Comparison of conventional and automated procedures for nitrogen, phosphorus, and potassium analysis of plant material using a single digestion. Agron. J. 59:240-243.

Turner, N. D., Diaz, A., Taddeo, S. S., Vanamala, J., McDonough, C. M., Dykes, L., Murphy, M. E., Carroll, R. J., and Rooney, L. W. 2006. Bran from black or brown sorghum suppresses colon carcinogenesis. FASEB J. 20:A599.

Yang, L., Browning, J. D., and Awika, J. M. 2009. Sorghum 3-deoxyanthocyanins possess strong phase II enzyme inducer activity and cancer cell growth inhibition properties. J. Agric. Food Chem. 57:1797-1804.

Zummo, N. 1980. Fusarium disease complex of sorghum in West Africa. Pages 11-15 in: Proc. Int. Workshop Sorghum Dis. ICRISAT Press, Hyderabad, India. Zummo, N. 1984. Fusarium root and stalk disease complex. Pages 25-29 in: Sorghum Root and Stalk Rots, a Critical Review. Proc. Consultative Group Discuss. Res. Needs Strat. Control Root Stalk Rot Dis., Bellagio, Italy. G. Rosenberg, ed. ICRISAT Press, Patancheru, India. 